Available online at: https://tsdr.psdku.unpad.ac.id/index.php/journal/index

Tourism and Sustainable Development Review Journal (TSDR)

ISSN 2722-2152 (online)

Volume 2 Number 2 (2021): 16-29

\title{
The Conflict of Place Identity at Cultural Heritage Tourism Site
}

\author{
Ahmad Nazrin Aris Anuar1, Aida Fazila Ab Aziz1, Nur Idzhainee Hashim1, \\ Norajlin Jaini' ${ }^{1}$, Firdaus Chek Sulaiman'1 \\ ${ }^{1}$ Centre of Studies for Park \& Amenity Management, Faculty of Architecture, Planning \& Surveying, \\ Universiti Teknologi MARA, Shah Alam, Selangor Darul Ehsan, Malaysia
}

\begin{abstract}
The cultural heritage tourism site is hard to maintain identity since it is not representing the real identity in the site. Alongside, diminishing of the place significance that occurs at the cultural tourism site also contributed to the conflict of place identity. By considering the issue that faced at cultural heritage tourism site, the aims of this study are to understanding the potential of conflict place identity at cultural heritage tourism site towards the domestic tourist perspectives. Two objectives for this study: i) to identify the factor conflict of place identity that affect the significance of cultural heritage tourism site, ii) to evaluate the significance of place attachment towards the conflict of place identity at cultural heritage tourism site. This study is using quantitative techniques and the domestic tourists as main respondents at Petaling Street, Kuala Lumpur. The result of this study showed that the factors of conflict place identity at cultural heritage tourism sites could affect the tourist's experiences and expectations about the tourism places. This study may inspire the stakeholders in handling the conflict of place identity and delivered better services to tourists for better services at cultural heritage tourism sites.
\end{abstract}

Keywords: Conflict, Cultural Heritage Tourism; Domestic Tourist; Place Attachment; Place Identity

This is an open access article under the CC-BY-NC license.

\section{INTRODUCTION}

The place identity for cultural heritage tourism sites relates to people and the environment, which implicates their attachment and perception. The identity describes the materiality whereby heritage provided an effective symbolic which support identity and place attachment. The resources in cultural heritage represent the identity of tourism places (Prats, 2009). According to World Tourism Organization (WTO) (2000), cultural heritage is defining the relationship place identity that gives significance to the identity of people, self-respect, and dignity to them. Cultural heritage tourism has objectives to gain related to sustainable development, such as for conservation of cultural resources, give visitor's experiences, use of interpretation resources, and can give profit from cultural resources (Norhasimah, Tarmiji, \& Azizul, 2014). These can strengthen the place identity and create place attachment towards the tourist.

Corresponding author

Ahmad Nazrin Aris Anuar, aek_2751@yahoo.com

DOI: https://doi.org/10.31098/tsdr.v2i2.47 
The importance of cultural heritage tourism has many reasons towards the identity and place attachment. It positively impacts the economy and society, which helps establish a strong identity of place and create place attachment for people. It helps to develop proper preservation management of the cultural heritage, with uses culture as the main resource, develop an understanding among people, support the culture, and lastly, it helps in an economy in the tourism industry (Norhasimah et al., 2014). The element in cultural heritage tourism was built by activities, definition or meaning of place, and physical shape. The perception gain by tourists from cultural heritage sites is generated from the sense of place, combine with their internal psychological and social processes.

The concept of heritage and concept of identity is relating to each other's because they hold the same meaning (Howard \& Graham, 2008). Identity can make the place different from the other places whereby make the place unique and have symbolic. This differentiation is important for the representation of the identity of place (Cortes, 2013). Tourism sites can attract many tourists' arrival due to their perception towards the attraction of culture itself. Cultural heritage tourism is indicating a major global industry that influences the economy of that country and also gives an actual identity for that country (Richard, 2007). It seems that the cultural heritage and identity of the place were linked and sometimes also can be as threatens toward local's culture and originality of community. Besides the various background of society, there also has an impact on the changes of demographics and behavior on society perception's and opinions. From the previous study in Europe, the researcher was clarified that more than $50 \%$ of tourists that visited Europe been motivated to travel by identity of cultural heritage that creates the attachment feeling with that place. The rising of the tourism industry was brought by the tourist normally from the higher education and expectation since they seek the new thing such as want to explore the new culture that differs from their usual environment (Urosevic, 2012).

Therefore, many of the scholars found that the place identity not only can be determining by the physical things but also they must look through the meaning and relationship between people and places. Hence, the cultural characteristics must include the tourist perceptions that influenced the place identity and place attachment. According to Anuar, Ridzuan, Jaini, Chek Sulaiman, and Hashim (2019), 39.7\% of respondents agreed that perception, practice, and a good attitude, will help them to practice the development of resources for learning, development, and experiences. This shows that the place identity not only can affect the significance of the place but also the perception of people and their experiences when they travel to the cultural heritage site. The cultural identity gained from tourists can constantly change in the process to explore different places because they tend to increase their quality of life. It holds power in differentiating the group of people. From this, it can contribute to simplifying that tourism can promote group formation (Cheng, 2016). This study aims to understand the potential of conflict place identity at cultural heritage tourism sites towards the domestic tourist perspectives. Therefore, the objectives of this study are: i) to identify the factor conflict of place identity that affect the significance of cultural heritage tourism site, and ii) to evaluate the significance of place attachment towards the conflict of place identity at cultural heritage tourism site. 


\section{LITERATURE REVIEW}

Cultural heritage is one of the tourism types in Malaysia. The important element in cultural heritage is divide into three whereby the formation of people, tangible cultural heritage, and intangible cultural heritage. Explanation on the tangible cultural heritage is about the physical elements such as buildings and monuments. At the same time, the intangible cultural heritage was referring to the significance of people's viewpoint and the way of their related to the cultural heritage of the Malaysian community (Rodzi, Ahmad Zaki, Syed Subli, 2016). Cultural heritage tourism was seen as that have the potential to improve the tourism industry and give benefit on economic growth for that country. According to Richter (1999), the conflict on culture heritage tourism because it grows without concerning it important, for example, the cultural heritage tourism was often seen as a thing to gain the benefit, especially on the economy.

In the globalized world, the tourism industry was being seen to become an opportunity for cultural and social contact, social exchange with communication. It makes the cultural identity and tourism have been linked together which the significant value and give an improvement in economic, social change and political. Cultural tourism has been identified as a sustainable alternative to mass tourism, which it was represents the best model for local development. In differentiation between other competitors, the optimally uses the genuine characteristic of destination and also the uniqueness of identity was taken into consideration for cultural identity (Urosevic, 2012). From this view, it not only can protect the cultural identity but also give strength to the value, lifestyle, and economy of local communities. Improving cultural tourism can give significant value to the quality of life of the local community and tourists, regenerate neglect of urban areas and increase the value of the real estate. The combination of cultural and tourism development policies acts as the key to promote the local destination as the place for desirable to live, work, and visit (Urosevic, 2012).

\section{The Conflict of Place Identity at Cultural Heritage Tourism}

The meaning of place is relating to the social development such as psychological that lead to perception. Meanwhile, the identity is explaining about the culture and way of life hold by people. In cultural characteristics, the type of place is the first component to develop image identity whereby important for tourism (Ummugulsum, 2017). Not only have that, but the characteristic identity of place also held the perspective toward historical and social such as culinary culture, historical building, and art. The characteristic like the building, the function of place, activities, sense of place, and emotional attachment developed the character of the place and gave the identity in cultural tourism.

Determining identity must base on its meaning and the relationship between people and place (Ujang, 2017). In other research also describe that place identity is a kind of group identity. Sometimes the place can be seen as group development, that people who come from the same place develop a group relation with the purpose to preserve and conserve the diversity of architectural attributes of place which form the place attachment between people (Cheng \& Jieyu, 2016). Other research also relates the place with describing the place identification. Place identification holds the similarity between social. Under social attribute toward a place, it has the sense of place that relating with the identity of culture community. Social community gives identity to that place that became one of the dependent variables (Clare \& Uzzell, 1996). 
Conflict may be defined as a struggle by people toward refusing the belief, significance, and ideas. In addition, conflict relates with inconsistency on people such as the struggle between individual, group of people, and social due to the material and interest (Diez \& Emily, 2007). Conflict also exists when people became dependent where they also acknowledge how the conflict may arise when they have different purposes and beliefs (Wilmot \& Hocker, 2010). Regarding the conflict of place identity toward culture heritage site, it happens due to the insufficient of resources, involvement in decision making that have a different opinion and ways relating with the cultural, government and social such as management of natural resources, debate on the technique used, and negotiate to agree (Schmid, 1998). The conflict raised may be due to the place not represent the actual identity anymore and diminishing the place significance that relates with the place attachment. The factor conflict of place identity has five variables, include degradation of the sense of place and physical feature, the transformation of the cultural landscape, tourism affect unique of place identities, culture heritage as a product for economic growth, and lastly is social change. The idea here affected the place identity toward tourists. There is generally a decrease in the intrinsic interest they have when coming to cultural heritage tourism sites.

\section{The Place Attachment for Cultural Heritage Tourism Site}

The definition of place attachment was influenced by the place identity, which places identity can create the place attachment. The significance of place attachment is used to define place identity. Both of these develop an affective relationship between tourists and place during their travel at that place. From that, it gives the impact and emotion, knowledge and belief, and behavior and action (Hidalgo \& Hernandez, 2001). Meaning the place and attachment created can affect the capability of an image from that place influences by the experiences and culture. Besides the place influences the people's identity (tourist and local community), it also produces and strengthens the relationship between social-culture values and way of life (Rapoport, 1977). The influence of the global culture is from the changing context of the urban center where it was considering the psychological examining that can explain the perception and attachment in the process of placemaking. The term of place attachment dimension is used to develop the identification of the identity of a place in developing and maintain self and group identity with its characteristic features (Ujang, 2017). Place attachment also can form the connection between a person and the setting of the environment surrounding. To produce urban places like the city center, planners and designers should mainly focus on the important quality of physical elements for place attachment (Zakariya, Norsidah, \& Khalilah, 2015).

Place attachment is also related to the place dependence that reflected the use of bonding between people and place. Place dependence was considered as the goal that relates with the behavior component, like a sense of place from the resident or community. It explains when the place is well identified and feel significant by the users and able to provide condition which it can fulfil its function need and support its behavior goal that known as an alternative. The quality of the current place that has availability of physical resources and social resources to satisfy the goal that directed the behavior, and how it uses to compare to other alternative places are two important components in place dependence (Stokols, 1983). The ways to associate the place dimension is by giving the information of what affective unique and feature sense of place that involve behavior or cognitive. The suggestion for this dimension the sense of place may reflect the intensity of feeling 
in the different levels (Grace, Chipuer, Heather, \& Bramston, 2003). The significance of place attachment for cultural heritage tourism sites has five variables which sense of place, emotional attachment, culinary culture, the influences of the physical element, activity, and image, and lastly, historic environment. All these variables can strengthen the place attachment at cultural heritage tourism sites.

\section{RESEARCH METHOD}

The primary data that is used for this study is the quantitative approach. For quantitative approach, it is acquired through the questionnaires survey at Petaling Street, Kuala Lumpur. Petaling Street is recognized as the cultural heritage trail in Kuala Lumpur. The place offered leisure activity and a shopping alley as the main attraction for the tourist that related with Chinese culture as an identity for Petaling Street (Ismail, Masron, \& Ahmad, 2015).

The researcher has used the probability sampling technique by using simple random sampling methods. Each respondent was chosen randomly to cover the domestic tourist from both male and female and various demographic characteristics. The questionnaires were distributed surrounding Petaling Street, Kuala Lumpur, from 20 October 2019 until 02 January 2020. At the process of data collection, 317 out of 384 respondents are chosen as the sample size, which is the response rate is $82.55 \%$, and the result of Cronbach's Alpha is stated in Table 1 .

Table 1. Result of Cronbach's Alpha

\begin{tabular}{lcc}
\hline \multicolumn{1}{c}{ Objective } & $\begin{array}{c}\text { Reliability Statistic (actual survey) } \\
\text { Cronbach's Alpha }\end{array}$ & N of item \\
\hline $\begin{array}{l}\text { Objective 1: To identify the factor conflict of place } \\
\text { identity that affect significant of cultural heritage } \\
\text { tourism site }\end{array}$ & 0.890 & 11 \\
\hline $\begin{array}{l}\text { Objective 2: To evaluate the significance of place } \\
\text { attachment towards the conflict of place identity at } \\
\text { the cultural heritage tourism site }\end{array}$ & 0.832 & 10 \\
\hline
\end{tabular}

\section{FINDINGS AND DISCUSSION}

\section{Identify The Factor Conflict Of Place Identity That Affects Significance Of Cultural Heritage Tourism Site}

This part is to answer the first objective of this study. The elements are divide into five variables which: i) degradation of the sense of place and physical feature, ii) transformation of the cultural landscape, iii) tourism affect unique of place identities, iv) culture heritage as a product for economic growth, and lastly is v) social change.

Degradation is the sense of place and physical features

As referred in Table 2, degradation of the sense of place and physical features shown the highest mean value 4.03 that belong to the change in physical features can affect the environment in tourism place. The percentage for agreeing is the highest with $57.4 \%$, whereby the percentage for strongly agree is the second highest with $25.9 \%$, which show that the tourists agreed with the 
change in physical features at cultural heritage tourism site. Meanwhile, the lowest mean value is 3.83 , which for degradation the sense of place meaning can result in the change and transformation of building and space. The highest percentage is $54.6 \%$ belongs to agreed, and the second-highest is $19.2 \%$ that belongs to strongly disagree. The effect of degradation sense of place meaning also may contribute to the threat of the quality on public spaces such as Petaling Street.

Table 2. Degradation of the sense of place and physical features

\begin{tabular}{|c|c|c|c|c|c|c|c|}
\hline \multirow[t]{2}{*}{ Description } & \multicolumn{5}{|c|}{ Percentage $(\%) /$ Frequency } & \multirow[t]{2}{*}{ Mean } & \multirow{2}{*}{$\begin{array}{c}\text { Std. } \\
\text { Deviation }\end{array}$} \\
\hline & 1 & 2 & 3 & 4 & 5 & & \\
\hline \multirow{2}{*}{$\begin{array}{l}\text { Degradation sense of place } \\
\text { meaning can result in the } \\
\text { change and transformation of } \\
\text { buildings and spaces }\end{array}$} & 1.6 & 7.3 & 17.4 & 54.6 & 19.2 & \multirow{2}{*}{3.83} & \multirow{2}{*}{0.877} \\
\hline & 5 & 23 & 55 & 173 & 61 & & \\
\hline \multirow{2}{*}{$\begin{array}{l}\text { Change in physical features can } \\
\text { affect the environment in } \\
\text { tourism place }\end{array}$} & 0.9 & 4.1 & 11.7 & 57.4 & 25.9 & \multirow[b]{2}{*}{4.03} & \multirow[b]{2}{*}{0.791} \\
\hline & 3 & 13 & 37 & 182 & 82 & & \\
\hline \multirow{2}{*}{$\begin{array}{l}\text { Degradation of physical feature } \\
\text { affect the perception about the } \\
\text { place visit }\end{array}$} & 0.9 & 6.3 & 16.7 & 54.3 & 21.8 & \multirow[b]{2}{*}{3.84} & \multirow[b]{2}{*}{0.845} \\
\hline & 3 & 20 & 53 & 172 & 69 & & \\
\hline
\end{tabular}

* Strongly disagree $=1$, disagree $=2$, neutral $=3$, agree $=4$ and strongly agree $=5$

Transformation of the cultural landscape

Table 3 shows the result of two variables under the element of the transformation of the cultural landscape. The highest mean value for rapid urban development leads to the destruction of historical buildings and elimination of traditional trade at the cultural place is 4.02 , with the highest percentage is $53.3 \%$ for agree and the second highest is strongly agree with $26.8 \%$. This shows that most respondents are agreed that with rapid urban development happen at cultural heritage tourism sites, it can cause destruction to the historical building which new developers are not enthusiastic about taking care of the historic building. The lowest mean value is 3.93 makes place losing its charm in the aspect of cultural and historical value with the highest percentage is agree with $59.3 \%$, and the second-highest percentage is $21.1 \%$ for strongly agree. It showed that under the aspect of cultural and historical value should be exposed to make sure people more appreciate and give consciousness about conserve the value of place attachment.

Table 3. Transformation of the cultural landscape

\begin{tabular}{|c|c|c|c|c|c|c|c|}
\hline \multirow[t]{2}{*}{ Description } & \multicolumn{5}{|c|}{ Percentage (\%)/ Frequency } & \multirow[t]{2}{*}{ Mean } & \multirow{2}{*}{$\begin{array}{c}\text { Std. } \\
\text { Deviation }\end{array}$} \\
\hline & 1 & 2 & 3 & 4 & 5 & & \\
\hline \multirow{2}{*}{$\begin{array}{l}\text { Make place losing its charm in } \\
\text { the aspect of cultural and } \\
\text { historical value }\end{array}$} & 1.6 & 5.7 & 12.3 & 59.3 & 21.1 & \multirow{2}{*}{3.93} & \multirow{2}{*}{0.837} \\
\hline & 5 & 18 & 39 & 188 & 67 & & \\
\hline \multirow{2}{*}{$\begin{array}{l}\text { Rapid urban development lead } \\
\text { to the destruction of historical } \\
\text { buildings and elimination of }\end{array}$} & 0.9 & 3.5 & 15.5 & 53.3 & 26.8 & \multirow{2}{*}{4.02} & \multirow{2}{*}{0.805} \\
\hline & 3 & 11 & 49 & 169 & 85 & & \\
\hline
\end{tabular}




\section{traditional trade at the cultural}

place

* Strongly disagree $=1$, disagree $=2$, neutral $=3$, agree $=4$ and strongly agree $=5$

Tourism affects unique place identities

Table 4 showed the result for tourism affect unique of place identities with the highest mean value is 3.96 that belong to development of mass cultural tourism can lead to the overcrowding or over-tourism at the cities, with the highest percentage is agree with $57.7 \%$ and the second highest is $21.5 \%$ for strongly agree. This show that the respondent is agreed when the mass cultural tourism happens, the overcrowding at the certain area in cultural heritage tourism site cannot be control due to the improper management on tourist's arrival. The lowest mean value is 3.92 , where rapid tourism can destroy the uniqueness of ethnic culture and heritage with the highest percentage goes to agree with $49.2 \%$ and second highest is $23.7 \%$ for strongly agree. It showed that respondent agrees with rapid tourism such as commercialization can lead to the destruction of ethnic culture and authenticity for cultural heritage tourism site.

Table 4. Tourism affect unique place identities

\begin{tabular}{lcccccccc}
\hline \multicolumn{1}{c}{ Description } & \multicolumn{9}{c}{ Percentage (\%)/ Frequency } & Mean & \multirow{2}{*}{$\begin{array}{c}\text { Std. } \\
\text { Deviation }\end{array}$} \\
\cline { 2 - 6 } & $\mathbf{1}$ & $\mathbf{2}$ & $\mathbf{3}$ & $\mathbf{4}$ & $\mathbf{5}$ & & & \\
\hline $\begin{array}{l}\text { Rapid tourism can destroy the } \\
\text { uniqueness of ethnic culture and } \\
\text { heritage }\end{array}$ & 0.6 & 3.5 & 23 & 49.2 & 23.7 & & \\
\cline { 2 - 6 } & 2 & 11 & 73 & 156 & 75 & 3.92 & 0.811 \\
\hline $\begin{array}{l}\text { The development of mass cultural } \\
\text { tourism can lead to overcrowding } \\
\text { or over-tourism in the cities }\end{array}$ & 0.9 & 2.5 & 17.4 & 57.7 & 21.5 & & \\
\cline { 2 - 6 } & 3 & 8 & 55 & 183 & 68 & & 0.757 \\
\hline
\end{tabular}

$*$ Strongly disagree $=1$, disagree $=2$, neutral $=3$, agree $=4$ and strongly agree $=5$

Culture heritage as a product for economic

Table 5 shows the result for cultural heritage as a product for economic with the highest mean value is 4.05 where the government used the urban heritage as the place branding and marketing to attract more tourists, with the highest percentage is $54.6 \%$ for agree, and second, highest is $28.1 \%$ for strongly agree. The result showed that the respondents are agreed when the government used the urban heritage as the place branding and marketing for the tourism industry in the global market for attracting tourists or visitors for the purpose to increase economic growth. The lowest mean value is 3.95 is for cultural heritage as the product can lead to a harmful impact on place identity and local culture, with the highest percentage of agreeing is $51.7 \%$ and the secondhighest for strongly agree is $24.6 \%$. The result showed that almost all the respondents agree when cultural heritage is used as the product for economic growth, it can lead to a harmful impact on place identities. 
Table 5. Culture heritage as a product for economic

\begin{tabular}{|c|c|c|c|c|c|c|c|}
\hline \multirow[t]{2}{*}{ Description } & \multicolumn{5}{|c|}{ Percentage (\%)/ Frequency } & \multirow[t]{2}{*}{ Mean } & \multirow{2}{*}{$\begin{array}{c}\text { Std. } \\
\text { Deviation }\end{array}$} \\
\hline & 1 & 2 & 3 & 4 & 5 & & \\
\hline \multirow{2}{*}{$\begin{array}{l}\text { Lead to harmful impact on place } \\
\text { identities and local culture }\end{array}$} & 0.9 & 3.8 & 18.9 & 51.7 & 24.6 & \multirow[b]{2}{*}{3.95} & \multirow[b]{2}{*}{0.819} \\
\hline & 3 & 12 & 60 & 164 & 78 & & \\
\hline \multirow{2}{*}{$\begin{array}{l}\text { The government only used the } \\
\text { urban heritage as the place } \\
\text { branding and marketing to } \\
\text { attract more tourist }\end{array}$} & 0.6 & 4.7 & 12 & 54.6 & 28.1 & \multirow[b]{2}{*}{4.05} & \multirow[b]{2}{*}{0.804} \\
\hline & 2 & 15 & 38 & 173 & 89 & & \\
\hline
\end{tabular}

* Strongly disagree $=1$, disagree $=2$, neutral $=3$, agree $=4$ and strongly agree $=5$

\section{Social change}

Table 6 showed the result of social change with the highest mean value is 3.97, which social change can alter the expected identity of the actual community at the cultural heritage site. The highest percentage is $58.4 \%$ for agree, and the second-highest is for strongly agree is $21.8 \%$. Most of the respondents are agreed that the change that happens in society, especially when they are an important element that represents the culture at that place, affects largely on parts of general society. The lowest mean for social change is the changed structural of existing community at cultural heritage site can affect the experience, where the mean value is 3.89. The highest percentage for this variable is agreed with $49.8 \%$, and the second-highest is going to neutral with 25.9\%. Respondents have mixed feelings regarding the statement because this depends on changing the structural local, which also give impacts the intangible cultural qualities of the neighborhood as they no longer represent the community culture of the place.

Table 6. Social change

\begin{tabular}{|c|c|c|c|c|c|c|c|}
\hline \multirow[t]{2}{*}{ Description } & \multicolumn{5}{|c|}{ Percentage (\%)/ Frequency } & \multirow[t]{2}{*}{ Mean } & \multirow{2}{*}{$\begin{array}{c}\text { Std. } \\
\text { Deviation }\end{array}$} \\
\hline & 1 & 2 & 3 & 4 & 5 & & \\
\hline \multirow{2}{*}{$\begin{array}{l}\text { Alter the expected identity about } \\
\text { the actual community at the } \\
\text { cultural heritage site }\end{array}$} & 0.6 & 4.1 & 15.1 & 58.4 & 21.8 & \multirow[b]{2}{*}{3.97} & \multirow[b]{2}{*}{0.768} \\
\hline & 2 & 12 & 48 & 185 & 69 & & \\
\hline \multirow{2}{*}{$\begin{array}{l}\text { The changed structural of the } \\
\text { existing community at cultural } \\
\text { heritage sites can affect the } \\
\text { experience }\end{array}$} & 0.6 & 2.2 & 25.9 & 49.8 & 21.5 & \multirow[b]{2}{*}{3.89} & \multirow[b]{2}{*}{0.780} \\
\hline & 2 & 7 & 82 & 158 & 68 & & \\
\hline
\end{tabular}

$*$ Strongly disagree $=1$, disagree $=2$, neutral $=3$, agree $=4$ and strongly agree $=5$

\section{To Evaluate The Significance Of Place Attachment Towards The Conflict Of Place Identity At Cultural Heritage Tourism Site}

This part is to answer the second objective of this study. The elements are divide into five variables which are: i) sense of place, ii) emotional attachment, iii) culinary culture, iv) influence of physical element, activity, and image, and v) historic environment. 
Sense of Place

Table 7 showed the result for the variable of sense of place with the highest mean value is 3.86 which it influences the way of people experiences, by their thought and imagine the place they visit. The highest percentage is $53.0 \%$ for agree, and the second-highest is strongly agree with $20.8 \%$. Majority of respondents agreed that sense of place also could influence the how to express their thought, change the way of people experiences, and imagine the place in which they live or travel. The lowest mean value is 3.79 for a sense of place give the symbolize that make place exclusive with the highest percentage $52.1 \%$ for agreeing and second highest is $20.8 \%$ for neutral. The result shows that the respondents have mixed feeling about the sense of place can make the place important and be symbolize to make place exclusive, differ from others tourism places.

Table 7. Sense of Place

\begin{tabular}{lcccccccc}
\hline \multirow{1}{*}{ Description } & \multicolumn{9}{c}{ Percentage (\%)/ Frequency } & Mean & \multirow{2}{*}{$\begin{array}{c}\text { Std. } \\
\text { Deviation }\end{array}$} \\
\cline { 2 - 7 } & $\mathbf{1}$ & $\mathbf{2}$ & $\mathbf{3}$ & $\mathbf{4}$ & $\mathbf{5}$ & & \\
\hline $\begin{array}{l}\text { Give the symbolize that make place } \\
\text { exclusive }\end{array}$ & 2.5 & 5.7 & 20.8 & 52.1 & 18.9 & & \\
\cline { 2 - 6 } & 8 & 18 & 66 & 165 & 60 & 3.79 & 0.901 \\
\hline $\begin{array}{l}\text { can influences the way people } \\
\text { experience, by their thought } \\
\text { imagine the place they visit }\end{array}$ & 2.2 & 4.1 & 19.9 & 53.0 & 20.8 & & \\
\cline { 2 - 6 } & 7 & 13 & 63 & 168 & 66 & 3.86 & 0.868 \\
\hline
\end{tabular}

* Strongly disagree $=1$, disagree $=2$, neutral $=3$, agree $=4$ and strongly agree $=5$

Emotional attachment

Table 8 showed the result for emotional attachment, with the highest mean value is 3.95 . The place attachment conveys the positive emotional bond between the places and tourists, with the highest percentage is $51.1 \%$ for agree and the second highest is $24.6 \%$ for strongly agree. The majority of respondents agree that emotional feelings can have positive influences on the places and also by that individual when they involve in a particular environmental setting. The lowest mean value is 3.93 for emotional attachment give the feel of sentimental value toward the environment surrounding Petaling Street. The highest percentage is $49.2 \%$ for agree, and the second-highest is $25.6 \%$ for strongly agree. It showed that the respondents agree emotional attachment gives the ability and chance for the tourists to form the attachment to many things, such as develop an attachment with the environment and places surround them when they travel at Petaling Street.

Table 8. Emotional attachment

\begin{tabular}{lcccccccc}
\hline \multirow{1}{*}{ Description } & \multicolumn{5}{c}{ Percentage (\%)/ Frequency } & Mean & Std. \\
\cline { 2 - 7 } & $\mathbf{1}$ & $\mathbf{2}$ & $\mathbf{3}$ & $\mathbf{4}$ & $\mathbf{5}$ & & \\
Deviation
\end{tabular}




\begin{tabular}{|c|c|c|c|c|c|c|c|}
\hline $\begin{array}{l}\text { Place attachment convey the } \\
\text { positive emotional bond between } \\
\text { the places and tourist }\end{array}$ & 1 & 14 & 62 & 162 & 78 & 3.95 & 0.804 \\
\hline
\end{tabular}

$*$ Strongly disagree $=1$, disagree $=2$, neutral $=3$, agree $=4$ and strongly agree $=5$

\section{Culinary culture}

Table 9 showed the highest mean value for culinary culture is 3.88. The local cuisine can attract tourists to visit the cultural heritage with the highest percentage is $44.8 \%$ for agree and the second highest is $25.9 \%$ for strongly agree. The respondents mostly are agreeing that when the tourist participates in the activities that involve the local cuisine, they can learn and understand about the local culture and feel a sense of belonging with the tourism places. The lowest mean value is to local food and cuisine give the element of memorable toward tourist experiences with 3.86. The highest percentage for this variable is agreed with $45.7 \%$, and the second is $24.0 \%$. The respondents agree that culinary culture gives a chance for them to have a clear understanding of tourism places.

Table 9. Culinary culture

\begin{tabular}{|c|c|c|c|c|c|c|c|}
\hline \multirow[t]{2}{*}{ Description } & \multicolumn{5}{|c|}{ Percentage (\%)/ Frequency } & \multirow[t]{2}{*}{ Mean } & \multirow{2}{*}{$\begin{array}{c}\text { Std. } \\
\text { Deviatior }\end{array}$} \\
\hline & 1 & 2 & 3 & 4 & 5 & & \\
\hline \multirow{2}{*}{$\begin{array}{l}\text { Local cuisines can attract tourists } \\
\text { to visit the cultural heritage site }\end{array}$} & 0.9 & 6.6 & 21.8 & 44.8 & 25.9 & \multirow[b]{2}{*}{3.88} & \multirow[b]{2}{*}{0.903} \\
\hline & 3 & 21 & 69 & 142 & 82 & & \\
\hline \multirow{2}{*}{$\begin{array}{l}\text { Local food and cuisine give the } \\
\text { element of memorable toward } \\
\text { tourist experiences }\end{array}$} & 0.6 & 6.3 & 23.3 & 45.7 & 24 & \multirow[b]{2}{*}{3.86} & \multirow[b]{2}{*}{0.875} \\
\hline & 2 & 20 & 74 & 145 & 76 & & \\
\hline
\end{tabular}

${ }^{*}$ Strongly disagree $=1$, disagree $=2$, neutral $=3$, agree $=4$ and strongly agree $=5$

The influence of physical element, activity, and image

Table 10 shows the highest mean value is 3.98 for activity and interesting attributes give the place a more important and safer public environment. The percentage for agreeing is the highest with $53 \%$, and second, highest is $24.9 \%$ for strongly agree. Majority respondents agreed that combination of different thing at places provide multi-choice and wide range of uses that available to people. The lowest mean value is 3.93 for cleanliness and good maintenance at the place can encourage the feeling of safety toward tourists with the highest percentage is $56.8 \%$ for agree and the second is strongly agree with $21.8 \%$. Respondents agree that comfort feeling can give a good and positive image that can be recognized by the tourist whereby the comfort is another successful attribute for tourism places that include the physical comfort, environmental factor, and psychological comfort. 
Table 10. The influence of physical element, activity, and image

\begin{tabular}{|c|c|c|c|c|c|c|c|}
\hline \multirow[t]{2}{*}{ Description } & \multicolumn{5}{|c|}{ Percentage (\%)/ Frequency } & \multirow[t]{2}{*}{ Mean } & \multirow{2}{*}{$\begin{array}{c}\text { Std. } \\
\text { Deviation }\end{array}$} \\
\hline & 1 & 2 & 3 & 4 & 5 & & \\
\hline \multirow{2}{*}{$\begin{array}{l}\text { Activity and interesting attributes } \\
\text { give the place a more important } \\
\text { and safer public environment }\end{array}$} & 0.6 & 3.2 & 18.3 & 53 & 24.9 & \multirow{2}{*}{3.98} & \multirow{2}{*}{0.785} \\
\hline & 2 & 10 & 58 & $168^{`}$ & 79 & & \\
\hline \multirow{2}{*}{$\begin{array}{l}\text { Cleanliness and good } \\
\text { maintenance at the place can } \\
\text { encourage the feeling of safety } \\
\text { toward tourist }\end{array}$} & 0.6 & 6.0 & 14.8 & 56.8 & 21.8 & \multirow{2}{*}{3.93} & \multirow[b]{2}{*}{0.812} \\
\hline & 2 & 19 & 47 & 180 & 69 & & \\
\hline
\end{tabular}

* Strongly disagree $=1$, disagree $=2$, neutral $=3$, agree $=4$ and strongly agree $=5$

Historic environment

Table 11 showed the result the highest mean value for historic towns and buildings could formulate a historic environment for tourism places with 3.98. The highest percentage is $51.1 \%$ for agree, and the second-highest is $25.6 \%$ for strongly agree. The respondents agree that the historic environment that included the historical building and arts can provide a unique visual image of the urban area, especially at Petaling Street. The lowest mean value for historic environment is 3.94, with the highest percentage for agree is $51.7 \%$, and the second-lowest percentage is $24.0 \%$ for neutral. The result indicates that the respondents have mixed feelings about the statement because it depends on the respondent feeling toward the environment at a tourism place.

Table 11. Historic environment

\begin{tabular}{|c|c|c|c|c|c|c|c|}
\hline \multirow[t]{2}{*}{ Description } & \multicolumn{5}{|c|}{ Percentage (\%)/ Frequency } & \multirow[t]{2}{*}{ Mean } & \multirow{2}{*}{$\begin{array}{c}\text { Std. } \\
\text { Deviation }\end{array}$} \\
\hline & 1 & 2 & 3 & 4 & 5 & & \\
\hline \multirow{2}{*}{$\begin{array}{l}\text { Historic town and building can } \\
\text { formulate historic } \\
\text { environment for tourism place }\end{array}$} & 0.3 & 3.5 & 19.6 & 51.1 & 25.6 & \multirow[b]{2}{*}{3.98} & \multirow[b]{2}{*}{0.787} \\
\hline & 1 & 11 & 62 & 162 & 81 & & \\
\hline \multirow{2}{*}{$\begin{array}{l}\text { play an important role to } \\
\text { create the history of urban } \\
\text { place }\end{array}$} & 0.3 & 1.6 & 24 & 51.7 & 22.4 & \multirow[b]{2}{*}{3.94} & \multirow[b]{2}{*}{0.744} \\
\hline & 1 & 5 & 76 & 164 & 71 & & \\
\hline
\end{tabular}

${ }^{*}$ Strongly disagree $=1$, disagree $=2$, neutral $=3$, agree $=4$ and strongly agree $=5$

\section{CONCLUSION}

The result of this study presents the significant interpretation of factors that influences the domestic tourist behavior towards the conflict of place identity at cultural heritage tourism site and indication how the factors influenced domestic tourist behavior, especially those who came at Petaling Street. Some tourism places in the world have already made a move in implementing some solution to improve the factor conflict of place identity as well as toward domestic tourist's perception, and the result was depending on how the stakeholders can adapt this implementation to their situations. 
The factors of conflict place identity were analyzed based on a few variables, which are degradation of the sense of place and physical feature, the transformation of the cultural landscape, tourism affects unique of place identities, culture heritage as a product for economic growth, and lastly is social change. The highest mean value for degradation of the sense of place and physical features is 4.03 , which belongs to the change in physical features that can affect the environment in a tourism place. The respondents agreed changed physical features at a tourism place may affect the expected environment or attraction that is supposed to represent tourists. Meanwhile, the highest mean value for the transformation of the cultural landscape is 4.02. With rapid urban development, it can cause destruction to the historical building which new developers are not willing to take care of the historical building at cultural heritage tourism sites. The highest mean value for the element tourism affects the uniqueness of place identities which development of mass cultural tourism can lead to the overcrowding or over-tourism at the cities is 3.96. Mass cultural tourism can create overcrowding by tourists at a certain area in cultural heritage tourism sites.

Next, the highest mean value for cultural heritage as a product for economic is 4.05 , which government used the urban heritage as the place branding and marketing to attract more tourists. The government used the urban heritage as the place branding and marketing to attract tourists or visitors for economic growth in the global market. Lastly, the highest mean value for social change is 3.97, which social change can alter the expected identity that is supposed to represent by the actual community at the cultural heritage site. It proves that the change in any part of society or community can affect another part largely in general society at cultural heritage tourism sites. From the findings, the respondents have mostly agreed with five-factor of conflict place identity affect the cultural heritage tourism site. This research shows the objective one was achieved where the factors of conflict place identity can affect the experiences and expectations of tourists at cultural heritage tourism sites the tourism. Meanwhile, the perception of tourists regarding this place also changed since they did not gain full experience like they were expected. The previous scholar found that when the cultural heritage tourism site loss or decrease the meaning of place identity, it contributes by giving potential problem in non-place and the place was lacking with local identity (Lai, Said, \& Kubota, 2013).

The finding shows that the significance of place attachment towards the conflict of place identity at cultural heritage tourism is measured with five variables such as sense of place, emotional attachment, culinary culture, the influences of physical element, activity, and image, and lastly, historic environment. All these variables will strengthen the place attachment at cultural heritage tourism sites. The highest mean value for a sense of place is 3.86 that belong to the sense of place that will be influenced the way of tourist's experiences, by their thought and imagine the place. The sense of place essentially can change the way people thinking about the place and also the impact of experiences. The highest mean value for variable emotional attachment is 3.95 that belong to the place attachment convey the positive emotional bond between the places and tourist. The emotions they gain may have a positive impact on a place and to an individual value been identified with the particular environmental setting. Meanwhile, the highest mean value for culinary culture is 3.88 belong to local cuisine that can attract tourists to visit the cultural heritage. It proved that the significance of culinary culture should be retained and provide the various kind of food since it can attract more tourists. Then, the highest mean value is 3.98 goes to activity, and interesting attributes give the place a more important and safer public environment. The 
combination of different thing at provide many of choice and wide range of uses that available to people. Lastly, the result of the highest mean value for historic environment is 3.98 that belong to historic town and building can formulate historic environment for tourism place. The historic environment that included the historical building can provide a unique visual image of the urban place at a cultural heritage tourism site. The previous research has stated that significant place attachment can raised the comfort feel by people where it considers another successful attribute for public places that include the physical comfort, environmental factor, and psychological comfort (Carr et al. l, 1992)

In conclusion, to minimize the possibility of conflict place identity at cultural heritage tourism sites, at this time, the recommendation is required to support the stakeholders. Firstly is to improve the structure of the local community. To highlight the Chinese culture as an actual identity at Petaling Street, the place should be managed and associated by the Chinese community itself from all perspectives. Second, to provide multi-choice of food culture at Petaling Street. It indicates that food culture will be created a strong identity for cultural heritage tourism sites by providing or offer the various kinds of local cuisine that relate with the Chinese culture toward tourists. The third is to conservation on a heritage building. To improve the heritage building, especially at Petaling Street, effective conservation planning should be implemented to ensure the heritage building will be sustained for the future generation. Lastly, gazetted Petaling Street as a heritage zone. From the gazetting, it will be maintained the tangible and intangible in cultural heritage tourism site.

\section{REFERENCES}

Anuar, A.N.A., Ridzuan, F.H., Jaini,N., Chek Sulaiman, F., and Hashim, N.I. (2019). The Impact of Overtourism Towards Local Community in Heritage City. Journal of Tourism \& Hospitality, 8,3(406), 1-5.

Carr, S., Francis, M., Rivlin, G., \& Stone, M. (1992). Public Space. Cambridge: Cambridge University Press

Cheng, Y. L., \& Jieyu. (2016). Place Identity: How Tourism Changes Our Destination. International Journal of Psychological Studies, 8 (2), 76-85

Clare, T., \& Uzzell, D. (1996). Place and Identity Processes. Journal of Environmental Psychology - Jenviron Psychol. 16, 205-220.

Cortes, M. M. (2013). Cultural Heritage and Urban Regeneration: The Conflict Between Identity and Development Strategies in the City of Valparaiso, Chile. Master Thesis: University College London

Diez, T., \& Emily, P. (2007). Conflict and Human Rights: A Theoretical Framework. SHUR Working Paper: Sixth Framework Programme

Grace, P. H., Chipuer, M., Heather, \& Bramston. (2003). Sense Of Place Among Adolescents and Adults in Two Rural Australian Towns: The Discriminating Features of Place Attachment, Sense Of Community And Place Dependence In Relation To Place Identity. Journal of Environmental Psychology. 23 (3), 273-287.

Hidalgo, M., \& Hernandez, B. (2001). Place attachment: Conceptual and Empirical Questions. Journal Of Environmental Psychology, 21, 273-281. 
Howard, P. \& Graham, B. (2008). The Ashgate Research Companion to Heritage and Identity. England \& USA: Ashgate Publishing Limited

Ismail, N., Masron, T., \& Ahmad, A. (2015). Development of Cultural Heritage Tourism: Issues and Challenges. Advances in Environmental Biology, 9(4) March 2015, 219-221.

Lai, L. Y., Said, I., \& Kubota, A. (2013). The Roles of Cultural Spaces in Malaysia's Historic Towns: The Case of Kuala Dungun and Taiping. Procedia-Social and Behavioral Sciences, 85, 602625.

Norhasimah, I., Tarmiji, M., \& Azizul, A. (2014). Cultural Heritage Tourism in Malaysia: Issues and Challenges. SHS Web of Conferences.

Prats, L. (2009). Heritage and Identity: Engagement and Demission in the Contemporary World. London: Routledge Publisher.

Rapoport, A. (1977). Human Aspects of Urban Form : Towards Man-Environment Approach To Urban Form And Design. Oxford: Pergamon Press.

Richards, G. (2007). Cultural Tourism: Global and Local Perspectives. London: Routledge.

Richter, L. (1999). The Politics of Heritage Tourism Development: Emerging Issue for the Milleium, London: Routledge Publisher.

Rodzi, N.I.M., Ahmad Zaki, S., Syed Subli, S.M.H. (2016). Sustainability of Cultural Heritage in World Heritage Site, Melaka. Asian Journal of Behavioural Studies. 1, (4). 45-55

Schmid, A. P. (1998). Thesaurus And Glossary Of Early Warning And Conflict Prevention Terms. London: FEWER Secretariat.

Stokols, D. S. (1983). Residential Mobility and Personal Well-being. Journal of Environmental Psychology, 3, 5-19.

Ujang, N. (2017). Place Attachment and Continuity of Urban Place Identity. Procedia - Social and Behavioral Sciences, 49 (2012), 156 - 167.

Ummugulsum, T. (2017). Culture, Identity and Tourism: An Evaluation of Cultural Tourism Potentials of Sirince (Turkey). Multidisciplinary Academic Conference AC-TTSS 2017.

Urosevic, N. (2012). Cultural Identity and Cultural Tourism Between The Local And The Global (A Case Study Of Pula, Croatia). Singidunum Journal 2012, 9 (1): 67-76.

Wilmot, W., \& Hocker, J. (2010). Interpersonal Conflict 8 Edition. McGraw-Hill Higher Education

World Tourism Organization (2000). Building a Sustainable Future for Asia-Pacific. WTO: Madrid (1997): Final Report, Asia Pacific Ministers' Conference on Tourism and Environment.

Zakariya, Norsidah, U., \& Khalilah. (2015). Place Attachment and the Value of Place in the Life of the Users. Procedia - Social and Behavioral Sciences, 168 (2015), 373-380. 